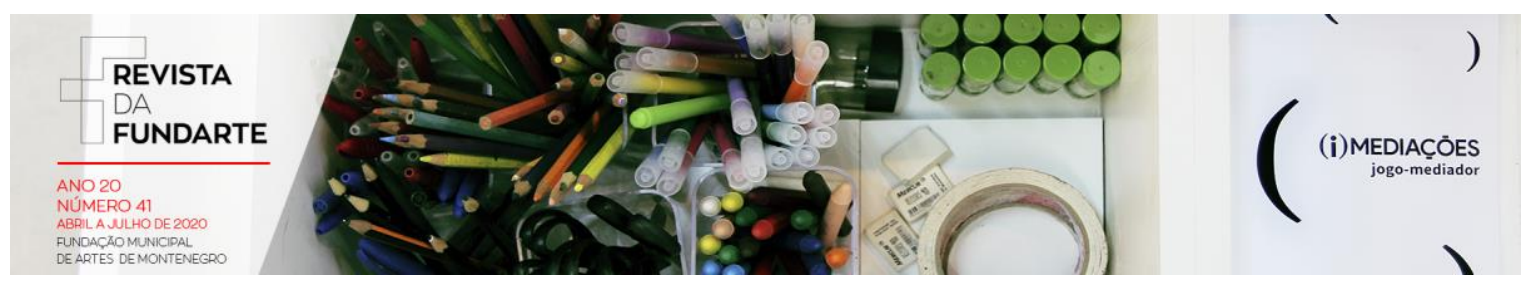

\title{
TRÊS VEZES TAINÁ, POSSÍVEIS CONTRIBUIÇÕES DE PELÍCULAS INDIGENISTAS PARA OS ANOS INICIAIS DO ENSINO FUNDAMENTAL
}

Maria Cristina Schefer

Tássia Monni Ferreira

DOI: http://dx.doi.org/10.19179/2F2319-0868.749

\section{TRÊS VEZES TAINÁ, POSSÍVEIS CONTRIBUIÇÕES DE PELÍCULAS INDIGENISTAS PARA OS ANOS INICIAIS DO ENSINO}

SCHEFER, Maria Cristina; FERREIRA, Tássia Monni. Três vezes Tainá, possíveis contribuições de películas indigenistas para os anos iniciais do ensino fundamental. Revista da FUNDARTE. Montenegro, p.01-25, ano 20, no 41, Abril/Junho de 2019.

Disponível em: http://.seer.fundarte.rs.gov.br/index.php/RevistadaFundarte/index> 30 de junho de 2020. 


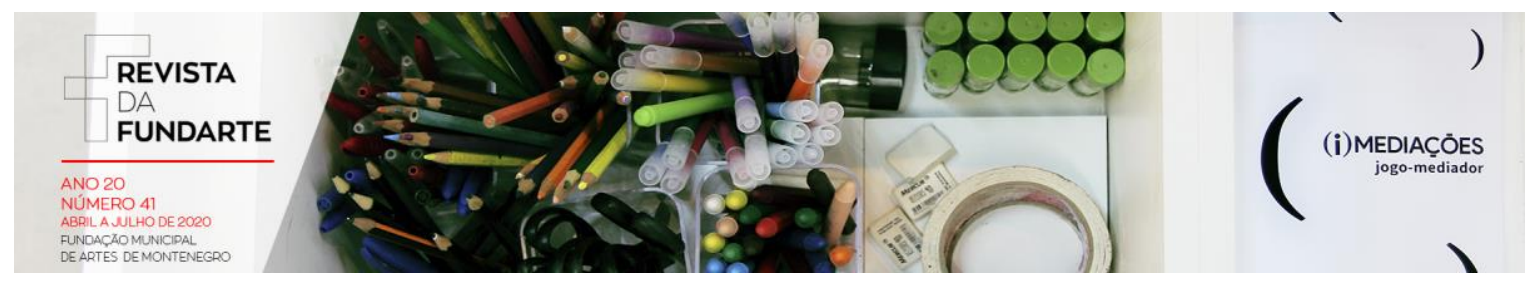

FUNDAMENTAL

Maria Cristina Schefer ${ }^{1}$ Tássia Monni Ferreira ${ }^{2}$

Resumo: Este estudo filmográfico teve como objetivo descrever e analisar os três filmes que relatam a história de Tainá, uma indígena que vive na Amazônia, produzidos no Brasil entre 2000 e 2013. Utilizaram-se como marco legal quatro documentos educacionais: a Lei 9.795/1999, que institui a Educação Ambiental no currículo; a Lei 11.645/2008, que torna obrigatório o "estudo da história e cultura afro-brasileira e indígena" no Ensino Fundamental e Médio; a Lei 13.006/2014, que obriga a exibição mensal de filmes nacionais nas escolas; e a Resolução CNE/CP n. 02/2017, que institui a BNCC. A pesquisa resultou nas seguintes constatações: os três filmes têm estrutura similar à de contos populares; são episódios curtos, apresentando as figuras de herói, anti-herói e ajudantes de herói, bem como elementos mágicos e desfechos finais. Tratam da exploração ilegal de recursos naturais na Amazônia e da importância dos povos indígenas para a preservação do lugar, podendo permitir leituras críticas e atender às demandas legais e didático-pedagógicas nos Anos Iniciais do Ensino Fundamental.

Palavras-chave: Pesquisa Filmográfica; Cultura Indígena; Educação Ambiental.

\title{
THREE TIMES TAINÁ, POSSIBLE CONTRIBUTIONS OF INDIGENOUS MOVIES TO THE EARLY GRADES OF ELEMENTARY SCHOOL
}

\begin{abstract}
This filmographic study aimed to describe and analyze 3 films produced in Brazil between 2000 and 2013 that report the story of Tainá, an Indigenous girl living in Amazonia. Four educationrelated documents were used: Act 9.795/1999, which included Environmental Education in the curriculum; Act 11.645/2008, which made the "study of the African-Brazilian and Indigenous history and culture" mandatory in both Elementary School and High School; Act 13.006/2014, which determined that Brazilian movies should be monthly screened in schools; and the Resolution CNE/CP n. 02/2017, which put BNCC into force. The results were the following: the structure of the three films is similar to that of folk tales; the episodes are short; the stories have a hero, an anti-hero, hero helpers, magical elements, and final denouements. The films focus on both the illegal exploitation of natural resources of Amazonia and the importance of Indigenous people for their preservation. The films may enable critic readings and meet the legal and didactic-pedagogic demands in the Early Grades of Elementary School.
\end{abstract}

Keywords: Filmographic Research; Indigenous culture; Environmental education.

\section{INTRODUÇÃO}

1 Dra. em Educação/Unisinos. Mestre em Letras e Cultura Regional- Ucs. Especialista em Alfabetização- UCs. Especialista em Gestão Escolar- EFICAZ. Pedagoga- Unijuí

2 Graduanda em Pedagogia/ 2019. Membro do Grupo de Estudos e Pesquisas em Educação, Diversidade Étnico- Racial e Direitos Humanos, vinculado ao Cnpq/Uergs.

SCHEFER, Maria Cristina; FERREIRA, Tássia Monni. Três vezes Tainá, possíveis contribuições de películas indigenistas para os anos iniciais do ensino fundamental. Revista da FUNDARTE. Montenegro, p.01-25, ano 20, no 41, Abril/Junho de 2019.

Disponível em: http://.seer.fundarte.rs.gov.br/index.php/RevistadaFundarte/index> 30 de junho de 2020. 


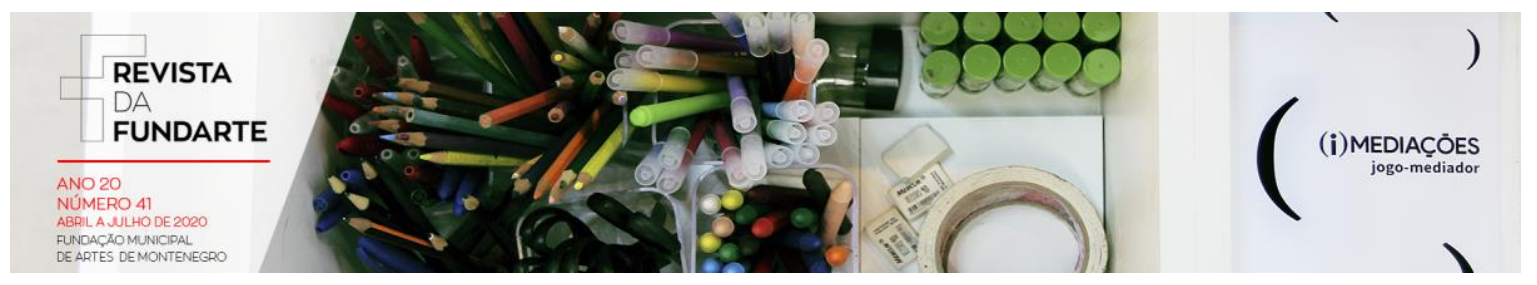

[...] Há tribos que começam a sua história desde quando o clã eram seres do espírito das águas. Outras trazem a sua memória animal como início da história, assim como há aquelas que iniciam a sua história a partir da árvore que foram. (JECUPÉ, 2002)

A invisibilidade dos povos indígenas e o compromisso destes com a preservação ambiental têm sido tema de muitas pesquisas acadêmicas nas últimas décadas. São análises fomentadas, sem sombra de dúvidas, a partir da Constituição Cidadã (1988), quando a autotutela foi "devolvida", formalmente, aos povos tradicionais.

Como estratégia para retirar indígenas de cenários lucrativos, os mais diversos exploradores têm criado fortes aparatos legais para regularização da grilagem de terras indígenas, sob o argumento do progresso e do "bem comum". Diante disso, falar nas questões indígenas e ambientais é falar no conflito: "propriedade versus pertencimento à 'terra".

Seja no Brasil de 1500, com portugueses, seja nos períodos imigratórios pósgrandes guerras (1914-1945), ou durante a ditadura militar (1964-1985), os indígenas sempre estiveram à mercê das vontades de não indígenas, daqueles que detêm o poder (capital) ao longo dos séculos. Seus valores e seus conhecimentos têm sido historicamente depreciados.

Este estudo aproveita o efeito sensibilizador das produções cinematográficas e a possibilidade de, mediante narrativas, ressignificar a realidade para demonstrar o quanto as produções Tainá: uma aventura na Amazônia (2000), Tainá: a aventura continua (2004) e Tainá: a origem (2013) podem atender (ao mesmo tempo) a algumas demandas da legislação educacional, como: a) a obrigatoriedade de promover a Educação Ambiental na escola; b) afirmar positivamente a tríade formadora da nação (índios-negros-brancos); c) exibir mensalmente filmes nacionais; d) seguir a Base Nacional Curricular Comum (BNCC) no que se refere ao

SCHEFER, Maria Cristina; FERREIRA, Tássia Monni. Três vezes Tainá, possíveis contribuições de películas indigenistas para os anos iniciais do ensino fundamental. Revista da FUNDARTE. Montenegro, p.01-25, ano 20, no 41, Abril/Junho de 2019.

Disponível em: http://.seer.fundarte.rs.gov.br/index.php/RevistadaFundarte/index> 30 de junho de 2020. 


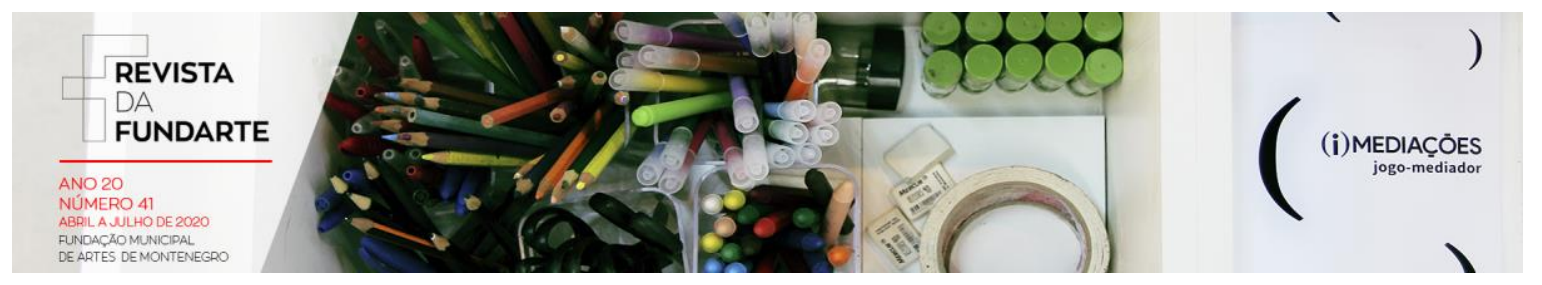

trabalho com suportes textuais contemporâneos (entre estes, os filmes) para o trabalho da Língua Portuguesa nos Anos Iniciais do Ensino Fundamental.

O texto está dividido em três partes. Primeiramente, apresentamos os marcos histórico/teórico e legal que fundamentam esta pesquisa. Na sequência, são trazidas a metodologia filmográfica e a análise dos dados. Por fim, fazemos as considerações finais.

\section{A SITUAÇÃO DOS INDÍGENAS NO BRASIL}

A luta indígena pelo direito existencial é secular - tem mais de 500 anos. Porém, as violências a que os indígenas vivem sujeitados têm sido continuamente ignoradas, negadas. Segundo Prézia (2017), os indígenas foram vítimas do maior evento genocida do Ocidente (na Modernidade). Mais de 70 milhões foram mortos, e cerca de 700 línguas nativas foram extintas. Informações similares são trazidas no Relatório Azul (2017), documento produzido pela Comissão de Direitos Humanos da Assembleia Legislativa do Estado do Rio Grande do Sul, que enfatiza, nas páginas iniciais, que, das cerca de 1.000 etnias indígenas que povoavam o Brasil no século $\mathrm{XVI}$, restam pouco mais de 300 .

Essa violência incluiu e tem incluído o sequestro material/territorial e cultural dos povos indígenas, em meio à argumentação das elites brasileiras pelo que chamam de "integração social". Nesse sentido, vale retomar episódios ocorridos durante a Ditadura Militar (no ínterim de mais ou menos 30 anos), entre 1964 e 1985, visto que, com o discurso protecionista, foi imposta a tutela estatal aos indígenas. Conforme Catafesto (2016, p. 59), "se tornou uma prática remover [...] indígenas para o interior das reservas e áreas demarcadas no norte do Estado [...] foram reprimidos e jogados pela força policial para longe de suas terras".

Essa condição de incapaz a que foram legalmente sujeitados os indígenas brasileiros perdurou até o fim do regime militar, como explica Catafesto (2016, p. 6061):

SCHEFER, Maria Cristina; FERREIRA, Tássia Monni. Três vezes Tainá, possíveis contribuições de películas indigenistas para os anos iniciais do ensino fundamental. Revista da FUNDARTE. Montenegro, p.01-25, ano 20, no 41, Abril/Junho de 2019.

Disponível em: http://.seer.fundarte.rs.gov.br/index.php/RevistadaFundarte/index> 30 de junho de 2020. 


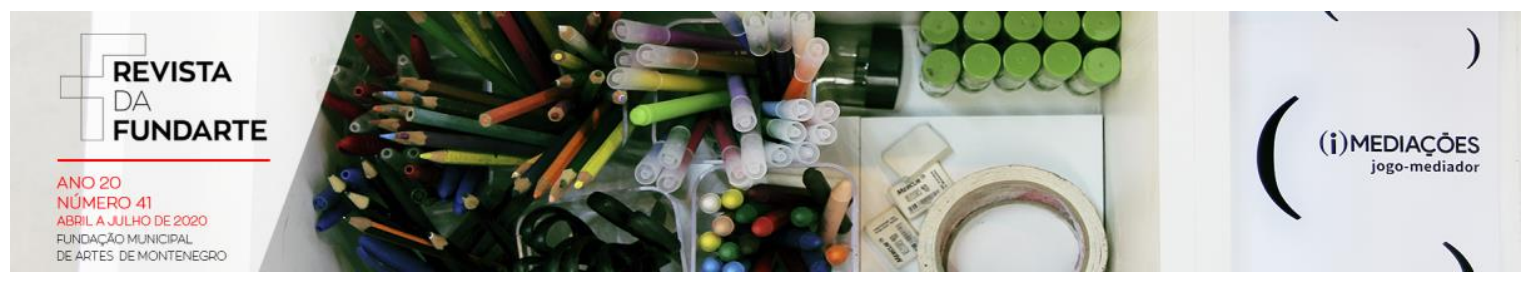

Com a Constituição Federal de 1988 é que a situação jurídica dos indígenas, enquanto relativamente capazes, foi substituída pelo critério da autodeterminação, [...] A década de 1990 foi marcada pelo ressurgimento da mobilidade indígena [...] Diversos acampamentos indígenas foram recriados nas beiras das estradas federais, nas rótulas de acesso às cidades e em vilas dentro do perímetro urbano.

Esse afastamento, por décadas, resultou em mais estranhamentos entre indígenas e não indígenas, produzindo a falta de empatia e, consequentemente, de solidariedade étnica. O pensamento de Bauman (2008) sobre o status de nativo garantido aos "homens de bem" em cada momento histórico é esclarecedor nesse sentido, pois revela a constante tentativa (de não indígenas) de retirar dos indígenas o direito de origem, da natividade brasileira, sendo relegados à condição de estranhos no próprio território.

\section{INDÍGENAS NO RIO GRANDE DO SUL, NO LITORAL NORTE}

Atualmente, os indígenas, no estado do Rio Grande Sul, segundo dados do Marco dos Povos Indígenas (2012, p. 04),

são integrantes dos povos Kaingang, Guarani, Charrua e Xokleng. A população total no estado, segundo o censo do IBGE de 2010, é de aproximadamente 33.000 indígenas $(0.33 \%$ da população total). Considerando-se outras fontes de informação, como a Fundação Nacional do Índio (FUNAI), há aproximadamente 19.600 indígenas no Rio Grande do Sul. O Instituto Socioambiental (ISA), organização não-governamental de atuação reconhecida nas questões dos direitos indígenas no Brasil, considera que há em torno de 17.600 indígenas no Rio Grande do Sul, porém algumas das aldeias identificadas pelo Instituto ainda não possuem dados de população. (grifos nossos)

Ainda segundo esse documento, produzido por órgãos estatais ${ }^{3}$ (idem), "a diferença entre esses dados se deve a critérios distintos de mapeamento". No caso do Instituto Brasileiro de Geografia e Estatística (IBGE), é levada em conta a

\footnotetext{
${ }^{3}$ Produzido em parceria entre: Secretaria do Planejamento, Gestão e Participação Cidadã; Secretaria da Educação; Secretaria Estadual de Obras Públicas, Irrigação e Desenvolvimento Urbano; Secretaria Estadual da Justiça e dos Direitos Humanos; Coordenação Executiva do Conselho Estadual dos Povos Indígenas; Departamento Autônomo de Estradas de Rodagem - DAER; Superintendência de Programas Especiais; Superintendência de Faixa Domínio.
}

SCHEFER, Maria Cristina; FERREIRA, Tássia Monni. Três vezes Tainá, possíveis contribuições de películas indigenistas para os anos iniciais do ensino fundamental. Revista da FUNDARTE. Montenegro, p.01-25, ano 20, no 41, Abril/Junho de 2019.

Disponível em: http://.seer.fundarte.rs.gov.br/index.php/RevistadaFundarte/index> 30 de junho de 2020. 


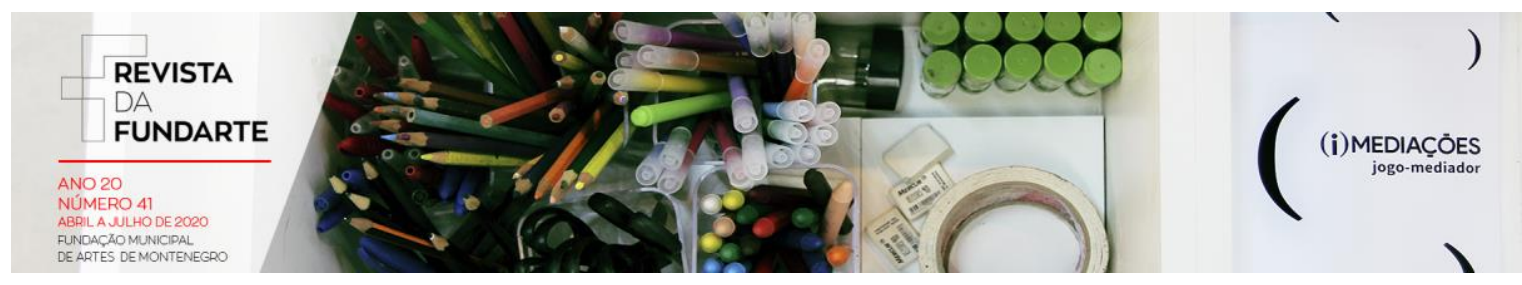

autoidentificação, contemplando-se no cálculo tanto indígenas que vivem em centros urbanos sob a racionalidade não indígena, quanto os que vivem em aldeamentos. Já nos demais casos, da Fundação Nacional do Índio (FUNAI) e do Instituto Sócio Ambiental (ISA), são quantificados apenas os indígenas que moram em terras demarcadas, terras por demarcar ou em reservas.

De modo geral, essas informações apontam para o fato de que $50 \%$ dos indígenas resistiram/resistem ao modo de vida "ocidental, capitalista". Número que possivelmente seria menor, não fosse a abertura para a interculturalidade, permitida a partir da Constituição de 1988, o que implicou repensar o papel dos povos tradicionais e a preservação ambiental nas mais diversas instâncias, inclusive no meio educacional.

No Litoral Norte do Rio Grande do Sul, composto por 21 municípios, lócus deste estudo, há cerca de 14 aldeias, distribuídas em sete municípios. Moram nelas, mais ou menos, 300 indígenas, predominantemente Guarani-Mbyá e Kaingang. São comunidades situadas em lugares periféricos, geralmente, sem os recursos naturais necessários para a subsistência.

Depois de um período longo de reassentamentos, em vista da ampliação da BR 101 (entre 2005 e 2011), em 2017, em uma ousada empreitada, um grupo de Guarani-Mbyá, formado por indígenas de várias aldeias da região, retomou a uma área da Mata Atlântica na cidade de Maquiné (RS). No lugar, até dezembro de 2016, havia funcionado uma fundação estadual de pesquisa agrária, extinta pelo então governo do estado.

Vale dizer que esse primeiro território "retomado" na região pode ser requerido pelos Guarani, não apenas devido ao reconhecimento antropológico da presença de seus ancestrais, mas também porque o local possui as características necessárias para o bem-viver (nhanderekó) dessa etnia. Para Gobbi et al. (2010, p. 21), "a Mata Atlântica contém uma diversidade de ambientes necessários ao modo de vida Mbyá-Guarani”.

SCHEFER, Maria Cristina; FERREIRA, Tássia Monni. Três vezes Tainá, possíveis contribuições de películas indigenistas para os anos iniciais do ensino fundamental. Revista da FUNDARTE. Montenegro, p.01-25, ano 20, no 41, Abril/Junho de 2019.

Disponível em: http://.seer.fundarte.rs.gov.br/index.php/RevistadaFundarte/index> 30 de junho de 2020. 


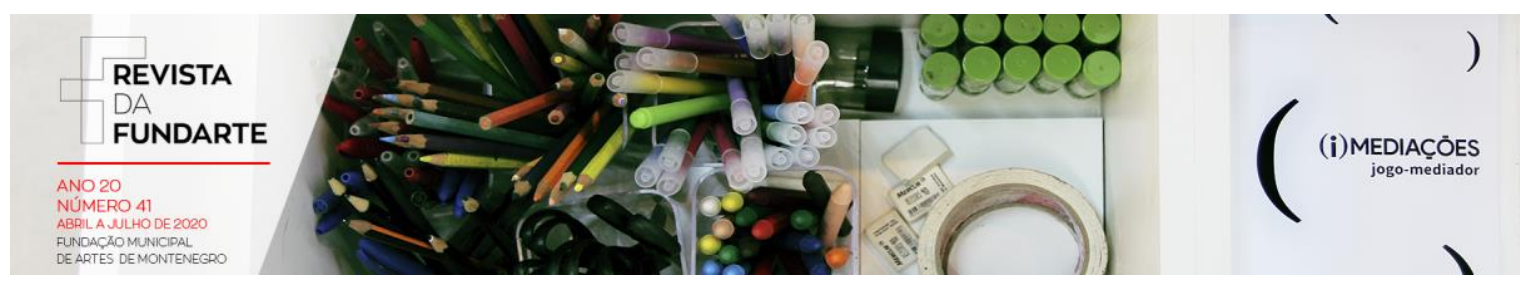

NOVOS PARADIGMAS PARA OS CONHECIMENTOS INDÍGENAS

Por si só, os marcos legais não se efetivam; porém, não é possível abrir mão deles, pois, se há direitos sendo negados, há instrumentos legais para que se busque justiça. Além disso, algumas leis, mais do que regrar a vida social, operam no campo das mudanças de mentalidades; desse modo, dificilmente seus efeitos serão imediatos, já que alterações dessa natureza são processuais. Segundo Sautchuk (2019), a legislação brasileira dá indícios do relacionamento das elites (europeias/brasileiras) com os povos tradicionais ao longo dos últimos 600 anos.

Quadro 1 - Linha cronológica de eventos que definiram a saga indígena no Brasil

\begin{tabular}{|c|c|}
\hline Período & Eventos e características \\
\hline 1494 & $\begin{array}{l}\text { O Tratado de Tordesilhas, em que Portugal e Espanha } \\
\text { dividiam o mundo entre eles - antes do descobrimento do Brasil, } \\
\text { portanto. A ação dos portugueses sempre foi de ocupação física } \\
\text { desses territórios no sentido oeste, todos já ocupados por } \\
\text { populações indígenas. Estes foram, entretanto, exterminados } \\
\text { indiscriminadamente. }\end{array}$ \\
\hline 1549 & $\begin{array}{l}\text { Com a instalação do governo-geral em Salvador, na Bahia, } \\
\text { apareceu a primeira regulamentação sobre os índios, em um } \\
\text { Regimento que garantia proteção aos aliados da Coroa e dava aos } \\
\text { padres jesuítas voz ativa nos assuntos relacionados aos índios. }\end{array}$ \\
\hline 1680 & $\begin{array}{l}\text { Um Alvará Régio instituiu o indigenato, que era o } \\
\text { reconhecimento do direito congênito e primário dos povos } \\
\text { nativos ao seu território tradicional, mas esse direito nunca foi } \\
\text { levado em conta. }\end{array}$ \\
\hline 1824 & $\begin{array}{l}\text { Os indianistas não foram nem citados na Constituição de } 1824 \text {. } \\
\text { Ainda eram considerados incapazes diante da Lei, cabendo ao } \\
\text { Estado catequizá-los e civilizá-los. Continuavam sendo mortos, } \\
\text { escravizados e explorados. Aldeias eram extintas sob a alegação } \\
\text { de que seus habitantes já faziam parte da sociedade brasileira. }\end{array}$ \\
\hline
\end{tabular}

SCHEFER, Maria Cristina; FERREIRA, Tássia Monni. Três vezes Tainá, possíveis contribuições de películas indigenistas para os anos iniciais do ensino fundamental. Revista da FUNDARTE. Montenegro, p.01-25, ano 20, no 41, Abril/Junho de 2019.

Disponível em: http://.seer.fundarte.rs.gov.br/index.php/RevistadaFundarte/index> 30 de junho de 2020. 


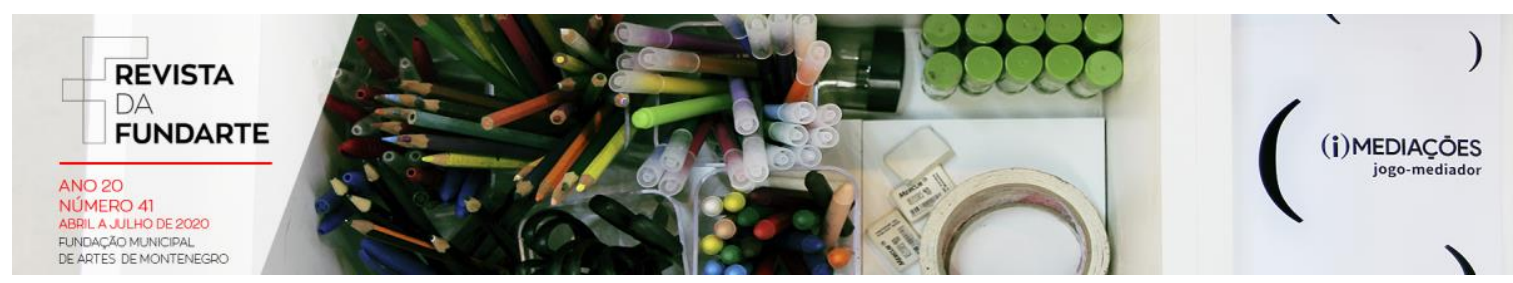

\begin{tabular}{|l|l|}
\hline 1850 & $\begin{array}{l}\text { Foi aprovada a Lei de Terras, a primeira lei que regulamentou a } \\
\text { propriedade privada no Brasil, assegurando também aos } \\
\text { índios o direito territorial e reafirmando o antigo indigenato, mas } \\
\text { outras leis entregavam a posse de terras tradicionais a colonos } \\
\text { brancos se fossem classificadas como vagas, por simples } \\
\text { declaração pessoal dos interessados na posse. Isso serviu de } \\
\text { pretexto para a expulsão de comunidades inteiras para possibilitar } \\
\text { a apropriação fraudulenta de terras - era a grilagem. }\end{array}$ \\
\hline 1889 & $\begin{array}{l}\text { Com a Proclamação da República, os positivistas mostravam-se } \\
\text { muito interessados pelos povos indígenas, vendo-os como } \\
\text { verdadeiras nações, com direito à autodeterminação. }\end{array}$ \\
\hline 1894 & $\begin{array}{l}\text { Na primeira Constituição da República, novamente, os índios não } \\
\text { foram citados, nem seus direitos territoriais foram } \\
\text { reconhecidos, embora algumas constituições estatuais Ihes } \\
\text { outorgassem alguns direitos territoriais. }\end{array}$ \\
\hline 1907 & $\begin{array}{l}\text { O Brasil, pela primeira vez, foi denunciado em um fórum } \\
\text { internacional por massacrar seus índios. }\end{array}$ \\
\hline 1910 & $\begin{array}{l}\text { Criação do Serviço de Proteção ao Índio (SPI), que garantiu a } \\
\text { posse de algumas terras tradicionais aos seus primeiros } \\
\text { ocupantes e as protegeu contra invasões. Da mesma forma, } \\
\text { reconheceu a importância de suas culturas originais e suas } \\
\text { instituições. }\end{array}$ \\
\hline 1967 & $\begin{array}{l}\text { Regime Militar: Extinção do SPI e criação da Fundação Nacional } \\
\text { do İndio (FUNAl). }\end{array}$ \\
\hline 1969 & $\begin{array}{l}\text { Emenda constitucional (EC- 001/69) definiu as terras indígenas } \\
\text { como patrimônio da União. }\end{array}$ \\
\hline 1988 & $\begin{array}{l}\text { No texto da Constituição Federal, o indígena tem direito de } \\
\text { usufruto dos recursos naturais, mas não à propriedade dos } \\
\text { territórios que ocupa, assegurando-se, assim, a preservação de } \\
\text { suas culturas. }\end{array}$ \\
\hline
\end{tabular}

(Fonte: Schefer, 2019)

A Constituição de 1988 inaugurou novos paradigmas para as relações interétnicas, trazendo em alguns de seus excertos, tanto o que já foi conquistado/efetivado, quanto aquilo que está sendo constantemente ameaçado/descumprido, valendo destacar:

SCHEFER, Maria Cristina; FERREIRA, Tássia Monni. Três vezes Tainá, possíveis contribuições de películas indigenistas para os anos iniciais do ensino fundamental. Revista da FUNDARTE. Montenegro, p.01-25, ano 20, no 41, Abril/Junho de 2019.

Disponível em: http://.seer.fundarte.rs.gov.br/index.php/RevistadaFundarte/index> 30 de junho de 2020. 


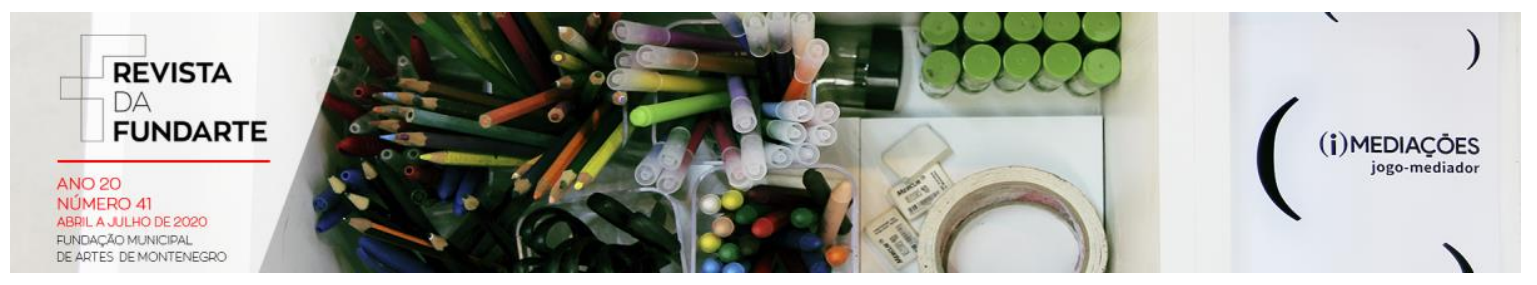

Art. 231. São reconhecidos aos índios sua organização social, costumes, línguas, crenças e tradições, e os direitos originários sobre as terras que tradicionalmente ocupam, competindo à União demarcá-las, proteger e fazer respeitar todos os seus bens. $\S 1^{\circ}$ - São terras tradicionalmente ocupadas pelos índios as por eles habitadas em caráter permanente, as utilizadas para suas atividades produtivas, as imprescindíveis à preservação dos recursos ambientais necessários a seu bem-estar e as necessárias à sua reprodução física e cultural, segundo seus usos, costumes e tradições. (grifos nossos)

O artigo acima pode ser entendido como a "ordem democrática" da Constituição Cidadã, para que um novo relacionamento com os indígenas fosse iniciado no país a partir da publicação da lei. Já os trechos grifados podem ser entendidos como as "letras ameaçadas" ou constantemente vulneráveis aos desmandos daqueles que detêm o poder/capital.

O fato apontado por Sautchuk (2019) de que 50\% dos indígenas continuam vivendo de modo tradicional revela que os aldeamentos são marcos de resistência ao modo de vida ocidental. Além disso, mostra que os indígenas, ao optarem pelo hábito secular da vida junto à natureza e pelo uso comedido de recursos, optam pela defesa da flora e da fauna. Desse modo, a associação dos direitos indígenas com a proteção ambiental é relevante para a Educação Ambiental no Brasil.

\section{OBRIGATORIEDADE DA EDUCAÇÃO AMBIENTAL NOS CURRÍCULOS}

Segundo o site ${ }^{4}$ oficial da Organização das Nações Unidas (ONU), a Conferência das Nações Unidas sobre o Ambiente Humano, realizada em 1972 em Estocolmo (Suécia), foi o marco para a instituição da pauta ambiental nas agendas públicas em todo o globo. Esse evento resultou no Manifesto Ambiental.

No Brasil, a Política Nacional do Meio Ambiente foi instituída com a Lei 6.938, de 1981. Na sequência, a Constituição de 1988 ratificou o compromisso do Brasil com a preservação ambiental, conforme o Art. 225:

\footnotetext{
${ }^{4}$ https://nacoesunidas.org/acao/meio-ambiente/

SCHEFER, Maria Cristina; FERREIRA, Tássia Monni. Três vezes Tainá, possíveis contribuições de películas indigenistas para os anos iniciais do ensino fundamental. Revista da FUNDARTE. Montenegro, p.01-25, ano 20, no 41, Abril/Junho de 2019.

Disponível em: http://.seer.fundarte.rs.gov.br/index.php/RevistadaFundarte/index> 30 de junho de 2020.
} 


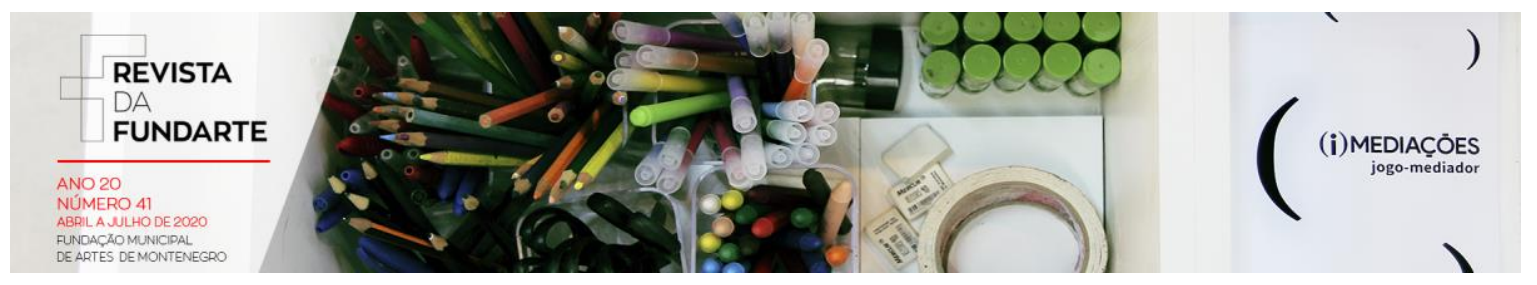

todos têm direito ao meio ambiente ecologicamente equilibrado, bem de uso comum do povo e essencial à sadia qualidade de vida, impondo-se ao Poder Público e à coletividade o dever de defendê-lo e preservá-lo para os presentes e futuras gerações. (BRASIL, 1988).

No mesmo artigo, inciso VI do parágrafo 1ำ, incumbe-se o poder público de "promover a educação ambiental em todos os níveis de ensino e a conscientização pública para a preservação do meio ambiente" (idem). Entretanto, a Lei de Diretrizes e Bases da Educação Nacional não incluiu, explicitamente, a Educação Ambiental como demanda escolar. Isso somente ocorreu após a promulgação da Lei $\mathrm{n} .{ }^{\circ}$ 9795/99, que instituiu a Política Nacional de Educação Ambiental (PNEA), a qual foi acolhida no Plano Nacional de Educação (PNE) (2001-2011), conforme os objetivos e metas para o Ensino Fundamental e Médio: "a Educação Ambiental, tratada como tema transversal, será desenvolvida como uma prática educativa integrada, contínua e permanente". (BRASIL, 2001) (grifos nossos).

A Resolução $n^{\circ} 2$ de 15 de junho de 2012 estabelece as Diretrizes Curriculares Nacionais para a Educação Ambiental (DCNEA) com a seguinte redação:

Art.2. A Educação Ambiental é uma dimensão da educação, é atividade intencional da prática social, que deve imprimir ao desenvolvimento individual um caráter social em sua relação com a natureza e com os outros seres humanos, visando potencializar essa atividade humana com a finalidade de torná-la plena de prática social e de ética ambiental (BRASIL, 2012, p. 2).

Apesar de todos esses avanços em políticas públicas educacionais, no que se referia à Educação Ambiental no período 1988-2012, Behrend et al. (2018) salientam que, na Base Nacional Curricular Comum, documento que atualmente está regrando a educação nacional, o termo Educação Ambiental aparece apenas uma vez entre os objetivos para o Ensino Fundamental e não aparece uma única vez entre os objetivos para a Educação Infantil. As autoras entendem que houve um retrocesso no compromisso educacional com as questões ambientais, uma possível mudança de paradigma.

SCHEFER, Maria Cristina; FERREIRA, Tássia Monni. Três vezes Tainá, possíveis contribuições de películas indigenistas para os anos iniciais do ensino fundamental. Revista da FUNDARTE. Montenegro, p.01-25, ano 20, no 41, Abril/Junho de 2019.

Disponível em: http://.seer.fundarte.rs.gov.br/index.php/RevistadaFundarte/index> 30 de junho de 2020. 


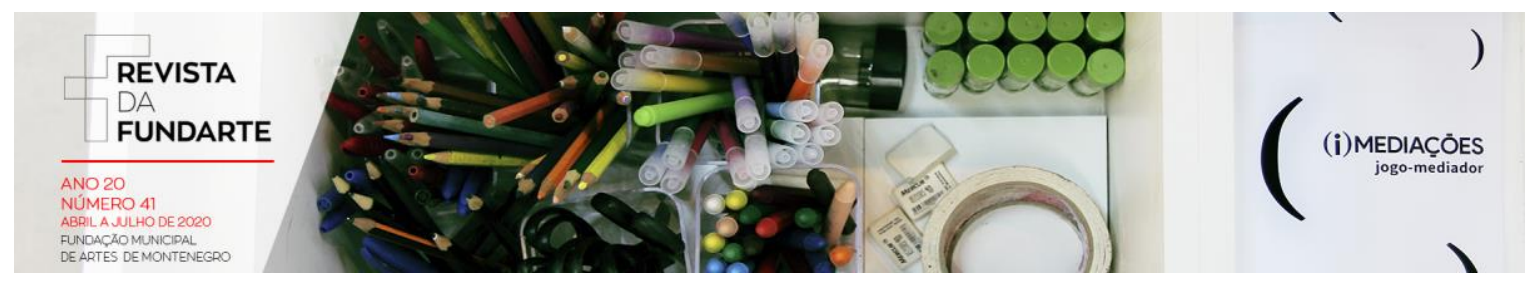

A TRÍADE FORMADORA DO PAÍS - ÍNDIOS, NEGROS E BRANCOS

A Lei 11.645 , de 10 de março de 2008, obriga as instituições de ensino a reconhecerem e difundirem a participação indígena na formação brasileira, obrigando a Lei de Diretrizes e Bases da Educação Nacional (LDB) a atualizar o Art. 26-A, que passou a ter a seguinte redação:

\begin{abstract}
nos estabelecimentos de ensino fundamental e de ensino médio, públicos e privados, torna-se obrigatório o estudo da história e cultura afrobrasileira e indígena.§ 1ㅇ $\mathrm{O}$ conteúdo programático a que se refere este artigo incluirá diversos aspectos da história e da cultura que caracterizam a formação da população brasileira, a partir desses dois grupos étnicos, tais como o estudo da história da África e dos africanos, a luta dos negros e dos povos indígenas no Brasil, a cultura negra e indígena brasileira e o negro e o índio na formação da sociedade nacional, resgatando as suas contribuições nas áreas social, econômica e política, pertinentes à história do Brasil. $\S 2$ o Os conteúdos referentes à história e cultura afrobrasileira e dos povos indígenas brasileiros serão ministrados no âmbito de todo o currículo escolar, em especial nas áreas de educação artística e de literatura e história brasileiras. (BRASIL, 2008). (grifos nossos)
\end{abstract}

Não há como falar da contribuição dos indígenas no Brasil sem falar no "açoite" que os constantes processos colonizadores impuseram a esses povos, fatos que não foram contados pela "história oficial". Por outro lado, incluir os indígenas como pertencentes à nação significa respeitar o status de nativos, dando-Ihes visibilidade, inclusive, pelo compromisso ético que sempre demonstraram com a natureza.

O fato de a legislação ter incluído a Educação Ambiental e a tríade formadora do país nos documentos educacionais (após a Constituição de 1988) demonstra a concepção pedagógica dos governantes e o compromisso assumido com o planeta, com a diversidade e com a vida em comunidade.

\title{
OBRIGATORIEDADE DA EXIBIÇÃO DE FILMES NACIONAIS
}

No campo das práticas didático-pedagógicas, uma normativa ainda pouco difundida nas escolas brasileiras que muito pode auxiliar no trabalho com a

SCHEFER, Maria Cristina; FERREIRA, Tássia Monni. Três vezes Tainá, possíveis contribuições de películas indigenistas para os anos iniciais do ensino fundamental. Revista da FUNDARTE. Montenegro, p.01-25, ano 20, no 41, Abril/Junho de 2019.

Disponível em: http://.seer.fundarte.rs.gov.br/index.php/RevistadaFundarte/index> 30 de junho de 2020. 


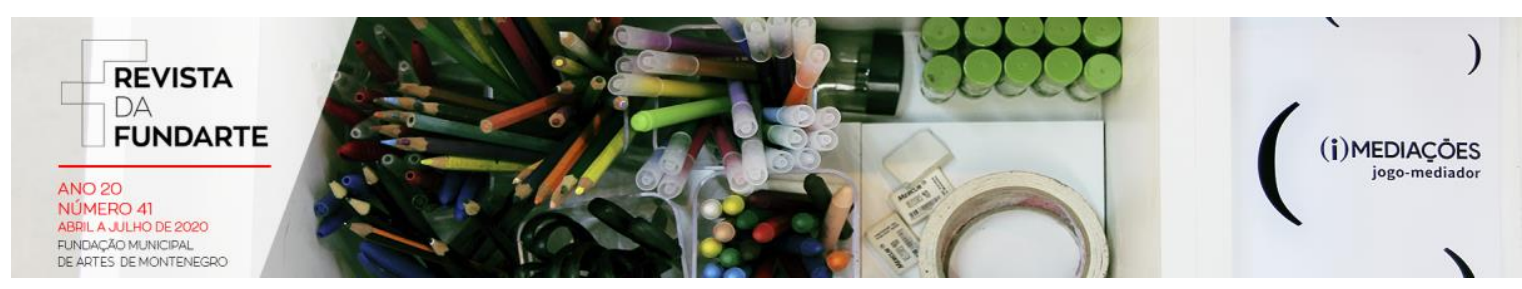

Educação Ambiental e a temática interétnica é a Lei 13.006, de 26 de junho de 2014, que acrescenta o $\S 8^{\circ}$ ao art. 26 da Lei no 9.394, de 20 de dezembro de 1996, para obrigar a exibição de filmes de produção nacional nas escolas de educação básica. Essa lei foi a evolução normativa do Projeto de Lei (PL) 7.507/2010, do senador Cristovam Buarque, que justificou o uso pedagógico e o incentivo a cinéfilos no espaço escolar nos seguintes termos: "o Brasil precisa de sala de cinema como meio para atender o gosto dos brasileiros pela arte e ao mesmo tempo. precisa usar o cinema na escola como instrumento de formação deste gosto" (BUARQUE, 20125).

Depois de muitos debates e busca de apoio junto a grupos especializados na sétima arte, é que a PL ganhou força legal, com a Lei 13.006/14. O cinema, conforme o documento, "constituirá componente curricular complementar integrado à proposta pedagógica da escola, sendo a sua exibição obrigatória por, no mínimo, 2 (duas) horas mensais." (BRASIL, 2014). Vale dizer que as crianças contemporâneas têm acesso a filmes no dia a dia, mesmo que em canais abertos de televisão, pois, segundo o IBGE (2018), o televisor está presente em cerca de $98 \%$ dos lares brasileiros.

Contudo, os filmes exibidos dentro da escola, mesmo quando já assistidos em outros ambientes, ganham a roupagem pedagógica e exigem do telespectador a criticidade diante dos pareceres do coletivo. O cinema, como as demais artes, é um artefato cultural e produz efeitos subjetivos, dependendo de onde, quando e por quem for recepcionado. Segundo Duarte (2002, p. 13), "o gosto pelo cinema, enquanto sistema de preferências, está ligado à origem social e familiar das pessoas e à prática de ver filmes". A escola, como instituição de ensino, pode oportunizar às crianças o contato com películas, que somente nesse espaço logram prestígio.

Em suma, a exibição de filmes na escola tem como princípio aprendizagens (socioculturais), mesmo quando as sessões de cinema forem planejadas para momentos de recreação. Esse cuidado obriga as equipes pedagógicas, os docentes, a definirem critérios para a seleção das películas, escolhendo filmes que levem em conta a idade do telespectador, a etapa de ensino e os objetivos educacionais.

\footnotetext{
${ }^{5}$ Em entrevista exibida na $7^{a}$ Mostra de Cinema de Ouro Preto (CINEOP) e IV Fórum da Rede LatinoAmericana de Educação, Cinema e Audiovisual (Rede Kino) em 2012.

SCHEFER, Maria Cristina; FERREIRA, Tássia Monni. Três vezes Tainá, possíveis contribuições de películas indigenistas para os anos iniciais do ensino fundamental. Revista da FUNDARTE. Montenegro, p.01-25, ano 20, no 41, Abril/Junho de 2019.

Disponível em: http://.seer.fundarte.rs.gov.br/index.php/RevistadaFundarte/index> 30 de junho de 2020.
} 


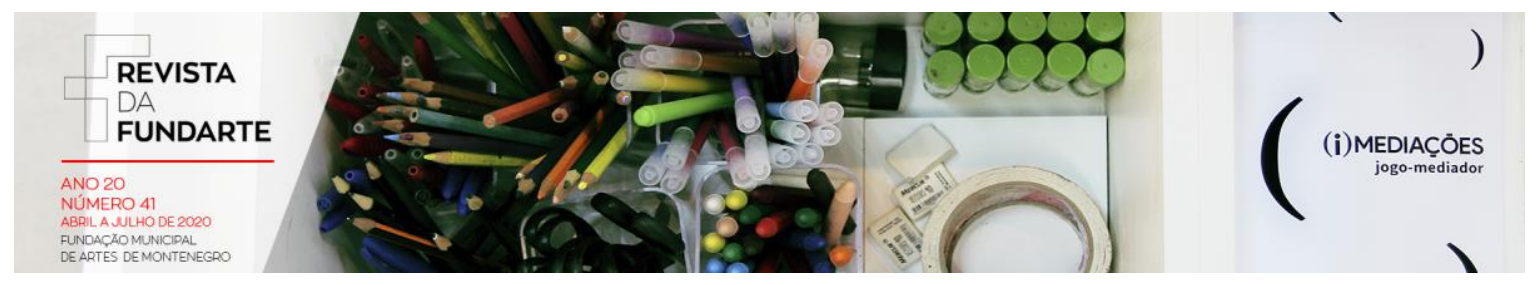

\title{
LINGUAGENS CONTEMPORÂNEAS NA BNCC
}

A Resolução ㄲo 2 de 22 de dezembro de 2017, do Conselho Nacional de Educação (CNE, CP) "institui e orienta a implantação da Base Nacional Comum Curricular a ser respeitada, obrigatoriamente, ao longo das etapas e respectivas modalidades no âmbito da Educação Básica" (BRASIL, 2017). Conforme o texto da lei, a BNCC é uma resposta ao demandado na Constituição de 1988, que definiu que devem ser "fixados conteúdos mínimos para o ensino fundamental, de maneira a assegurar formação básica comum e respeito aos valores culturais e artísticos, nacionais e regionais". (BRASIL, 1988).

Coube-nos, neste estudo, buscar na Base Nacional Curricular Comum (BNCC/ 2018) especificidades do Ensino Fundamental no que concerne à área das Linguagens, da Língua Portuguesa. Conforme o documento, "o Ensino Fundamental, com nove anos de duração, é a etapa mais longa da Educação Básica, atendendo estudantes entre 6 e 14 anos". (BRASIL, 2018, p. 57). Do $1^{\circ}$ ao $5^{\circ}$ ano, as crianças com idades entre seis e 11 anos frequentam os "anos iniciais" do Ensino Fundamental. Como também consta na BNCC,

\begin{abstract}
nesse período da vida, as crianças estão vivendo mudanças importantes em seu processo de desenvolvimento que repercutem em suas relações consigo mesmas, com os outros e com o mundo. Como destacam as DCN, a maior desenvoltura e a maior autonomia nos movimentos e deslocamentos ampliam suas interações com o espaço; a relação com múltiplas linguagens, incluindo os usos sociais da escrita e da matemática, permite a participação no mundo letrado e a construção de novas aprendizagens, na escola e para além dela; a afirmação de sua identidade em relação ao coletivo no qual se inserem resulta em formas mais ativas de se relacionarem com esse coletivo e com as normas que regem as relações entre as pessoas dentro e fora da escola, pelo reconhecimento de suas potencialidades e pelo acolhimento e pela valorização das diferenças. (BRASIL, 2018, p. 58). (grifos nossos)
\end{abstract}

As crianças dos anos iniciais necessitam de currículos com conteúdos que atendam a esse aumento de interações sociais, para que possam inserir-se

SCHEFER, Maria Cristina; FERREIRA, Tássia Monni. Três vezes Tainá, possíveis contribuições de películas indigenistas para os anos iniciais do ensino fundamental. Revista da FUNDARTE. Montenegro, p.01-25, ano 20, no 41, Abril/Junho de 2019.

Disponível em: http://.seer.fundarte.rs.gov.br/index.php/RevistadaFundarte/index> 30 de junho de 2020. 


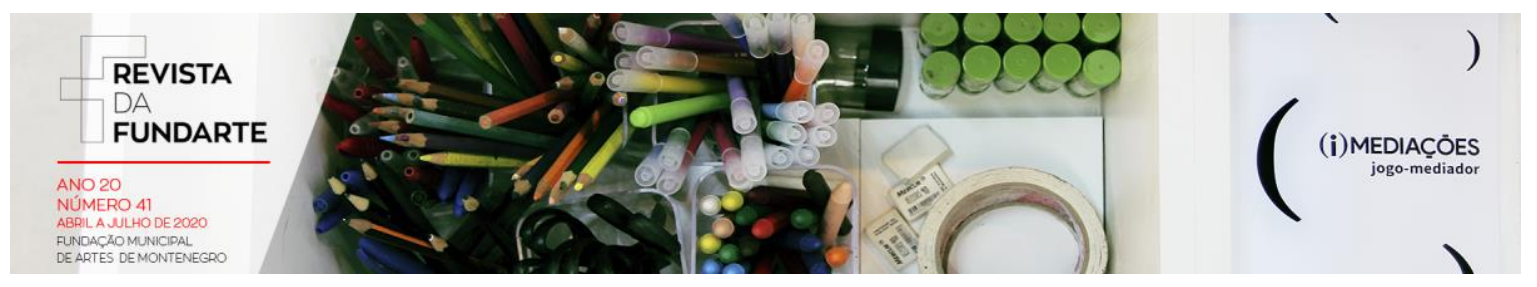

criticamente no coletivo, compreendendo e respeitando as diferenças. Como pode ser lido na BNCC,

as atividades humanas realizam-se nas práticas sociais, mediadas por diferentes linguagens: verbal (oral ou visual-motora, como Libras, e escrita), corporal, visual, sonora e, contemporaneamente, digital. Por meio dessas práticas, as pessoas interagem consigo mesmas e com os outros, constituindo-se como sujeitos sociais. Nessas interações, estão imbricados conhecimentos, atitudes e valores culturais, morais e éticos. (BRASIL, 2018, p. 63). (grifos nossos)

Para tanto, na BNCC, para os anos iniciais do Ensino Fundamental, estão elencados na área de Linguagens os seguintes componentes curriculares: Língua Portuguesa, Arte e Educação Física. Sendo que

ao componente Língua Portuguesa cabe, então, proporcionar aos estudantes experiências que contribuam para a ampliação dos letramentos, de forma a possibilitar a participação significativa e crítica nas diversas práticas sociais permeadas/constituídas pela oralidade, pela escrita e por outras linguagens. (BRASIL, 2018, p. 67-68).

Dentro do componente Língua Portuguesa, no Eixo Leitura, são tratadas as "práticas de linguagem, que decorrem da interação ativa do leitor/ouvinte/espectador com os textos escritos, orais e multissemióticos e de sua interpretação". (BRASIL, 2018, p. 71). A questão do uso de linguagens textuais contemporâneas é enfatizada na BNCC, nos seguintes termos:

leitura no contexto da BNCC é tomada em um sentido mais amplo, dizendo respeito não somente ao texto escrito, mas também a imagens estáticas (foto, pintura, desenho, esquema, gráfico, diagrama) ou em movimento (filmes, vídeos etc.) e ao som (música), que acompanha e cossignifica em muitos gêneros digitais. (BRASIL, 2018, p. 72) (grifos nossos).

No que se refere às 10 competências a serem desenvolvidas pelos leitores/telespectadores em Língua Portuguesa no Ensino Fundamental, de acordo com a BNCC, duas são destacadas aqui, porque entendemos que são fundamentais para abordar questões do respeito à diversidade, foco deste estudo, a saber:

SCHEFER, Maria Cristina; FERREIRA, Tássia Monni. Três vezes Tainá, possíveis contribuições de películas indigenistas para os anos iniciais do ensino fundamental. Revista da FUNDARTE. Montenegro, p.01-25, ano 20, no 41, Abril/Junho de 2019.

Disponível em: http://.seer.fundarte.rs.gov.br/index.php/RevistadaFundarte/index> 30 de junho de 2020. 


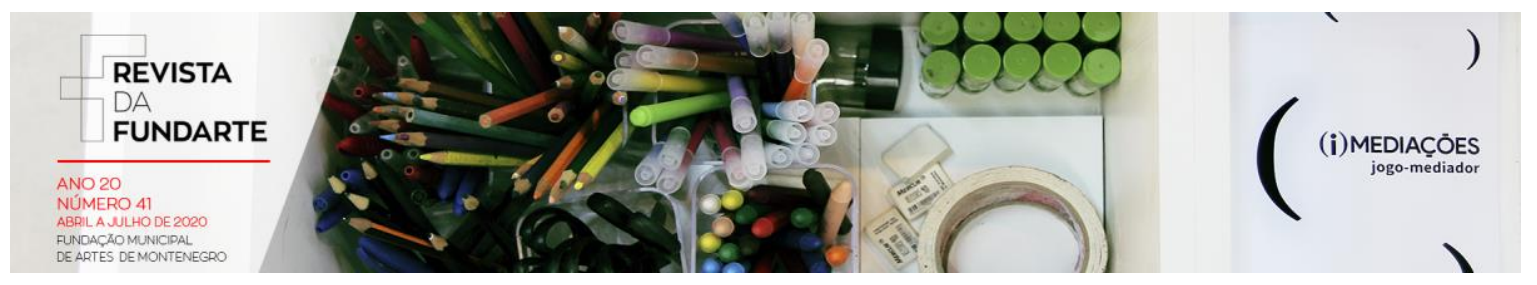

6. Analisar informações, argumentos e opiniões manifestados em interações sociais e nos meios de comunicação, posicionando-se ética e criticamente em relação a conteúdos discriminatórios que ferem direitos humanos e ambientais; 7. Reconhecer o texto como lugar de manifestação e negociação de sentidos, valores e ideologias. (BRASIL, 2018, p. 87).

Diante do que a BNCC orienta para a Língua Portuguesa, mais especificamente para os anos iniciais do Ensino Fundamental, coube-nos selecionar narrativas filmográficas que pudessem promover diálogos com as crianças brasileiras, gaúchas, litorâneas, que convivem diariamente com notícias discriminatórias sobre as populações indígenas, bem como de desrespeito à natureza.

\section{DA UNIÃO DAS DEMANDAS LEGAIS PARA O ESTUDO}

Este estudo pode ser entendido também como um exercício de planejamento de ensino para o atendimento das quatro demandas legais apresentadas nos parágrafos anteriores: promoção da Educação Ambiental; inclusão do povo indígena como parte da formação da nação; obrigatoriedade de exibição de filmes nacionais nas escolas; e Base Nacional Curricular Comum.

Ao selecionarem-se as três produções de Tainá, entre 2000 e 2013 no Brasil, levou-se em conta a indicação de faixa etária desses filmes: infanto-juvenil - daí a possibilidade de exibição na Educação Infantil e nos Anos Iniciais do Ensino Fundamental. Diante da riqueza dos episódios, que entendemos como partes de um movimento da sétima arte engajada, nesse caso, em prol dos povos indígenas e da natureza, salienta-se que essas películas podem promover reflexões, também com jovens e adultos/professores.

\section{METODOLOGIA: UM ESTUDO FILMOGRÁFICO}

Este "estudo filmográfico" (FABRIS, 2005) constitui-se em um desafio: o de demonstrar o potencial didático-pedagógico das três narrativas selecionadas, sem,

SCHEFER, Maria Cristina; FERREIRA, Tássia Monni. Três vezes Tainá, possíveis contribuições de películas indigenistas para os anos iniciais do ensino fundamental. Revista da FUNDARTE. Montenegro, p.01-25, ano 20, no 41, Abril/Junho de 2019.

Disponível em: http://.seer.fundarte.rs.gov.br/index.php/RevistadaFundarte/index> 30 de junho de 2020. 


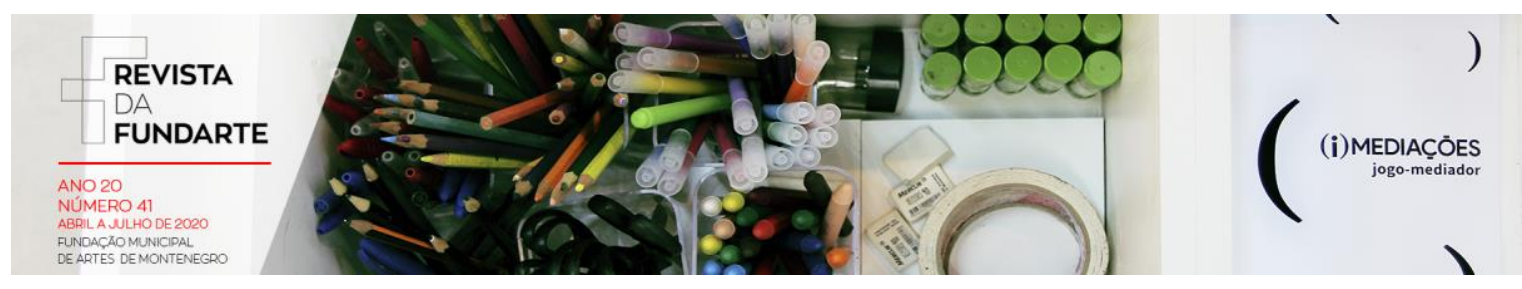

no entanto, banalizar a exibição de filmes dentro das escolas, nem simplificar o compromisso da educação com a conscientização sobre as questões ambientais e indígenas.

Para Fabris (2005, p. 121), "quando nós, pesquisadoras e pesquisadores da educação, escolhemos o cinema como campo para nossas investigações, rompe-se a primeira fronteira, aquela que separa a comunicação e a educação". Além disso, em se tratando de examinar filmes de aventuras, a fim de indicá-los como atividades escolares, propõe-se fomentar a fantasia do "herói que vence o mal", tão requerida e importante nesta etapa da vida humana que é fase entre os seis e os 11 anos de idade, quando as crianças costumam frequentar os primeiros anos do Ensino Fundamental.

A utilização de filmes de aventura com o objetivo de ensinar uma determinada especificidade curricular pode levar o espectador à sensibilização e ao exercício de alteridade com o personagem que deseja proteger. Essas películas, "imagens em movimento", segundo Fabris (2005, p. 118), "nos interpelam de um modo avassalador porque não dispensam o prazer, o sonho e a imaginação [...] embaralham as fronteiras do que entendemos por realidade e ficção". O empreendimento de decupar (dividir em categorias) as produções de Tainá com a finalidade de evidenciar o tipo de narrativa de que estávamos tratando e os diferentes conteúdos, tanto a Educação Ambiental quanto o papel dos indígenas na preservação da natureza, necessitou de um estudo rigoroso. Isso se deu por meio de uma série de visualizações/leituras de cada filme pelas pesquisadoras: Tainá, uma aventura na Amazônia, 2000; Tainá, a aventura continua, 2004; Tainá, a origem, 2013.

Em um primeiro momento, os filmes foram assistidos/lidos apenas para a familiarização com os episódios. Em um segundo momento, optamos por verificar o que havia de comum nas tramas vivenciadas por Tainá. Para tanto, organizamos o quadro 2, que nomeamos como "Evidências de que as narrativas se assemelham a contos populares", subdividido a partir das seguintes características: desfecho inicial, herói, ajudantes de herói, anti-herói, elemento mágico, desfecho final. Na sequência,

SCHEFER, Maria Cristina; FERREIRA, Tássia Monni. Três vezes Tainá, possíveis contribuições de películas indigenistas para os anos iniciais do ensino fundamental. Revista da FUNDARTE. Montenegro, p.01-25, ano 20, no 41, Abril/Junho de 2019.

Disponível em: http://.seer.fundarte.rs.gov.br/index.php/RevistadaFundarte/index> 30 de junho de 2020. 


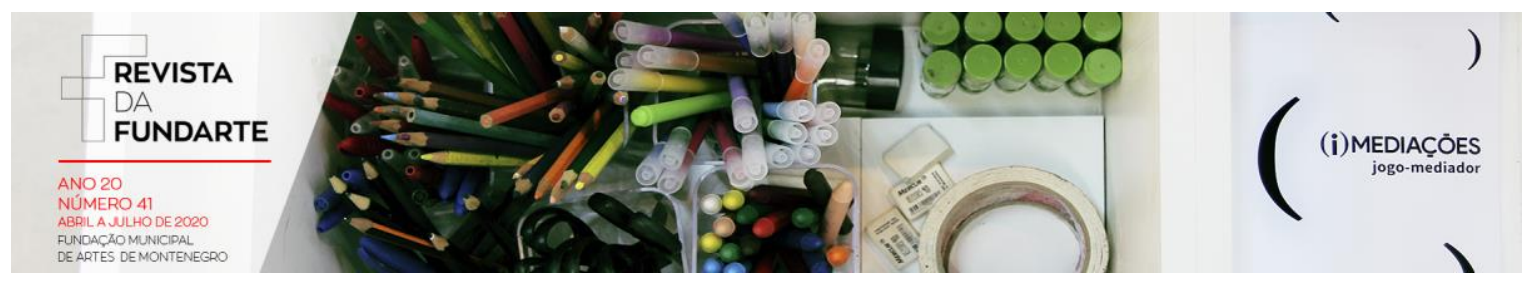

o filme foi assistido para buscar, nas falas dos personagens indígenas, aprendizagens significativas, e organizamos então o quadro 3, intitulado "Educação Ambiental e Cultura Indígena”. Paralelamente, fizemos a análise do conteúdo dos quadros.

\section{DOS OBJETOS DE ANÁLISE}

Os resumos abaixo foram escritos a partir da visualização, pelas pesquisadoras, das três narrativas. Neles estão evidenciadas as questões que reforçam o potencial didático-pedagógico de Tainá (2000, 2004, 2013).

O filme Tainá, uma aventura na Amazônia (2000) começa com uma cena bem marcante, em que Tainá e o avô, Tigê, estão diante de uma grande árvore. Esta representa a força da tradição para a cultura indígena, e o avô explica que cada animal e cada planta devem ser respeitados como tal.

Tainá, desde o início da narrativa, é apresentada como uma guardiã da floresta, libertando animais aprisionados em armadilhas e destruindo outras tantas para atrapalhar os contrabandistas da floresta. Algumas ações dela colocam-na em uma situação de risco, e ela passa a ser perseguida pelos vilões da história: Shoba, Biriba e Boca, todos traficantes de animais silvestres. Os traficantes estavam atrás de um filhote de macaco chamado Catu, que quer dizer "bonito" na língua da etnia da Tainá.

Quando Tigê e Tainá decidem seguir para outra região da floresta, Tigê morre. A relação com a morte (o chamado do rio) em meio a uma reação tranquila de Tainá demonstra diferenças culturais entre os indígenas e não indígenas.

Sozinha, Tainá prossegue em sua luta de proteção da floresta, até encontrar o jovem aviador Rudi, que se torna um amigo. Rudi leva a menina para uma cidade ribeirinha, onde vivem Isabel e seu filho, Joninho, o "menino com cabelos de fogo", como diz Tainá. Joninho é um menino urbano e não tem nenhum interesse pela natureza, porém, ele e Tainá iniciam uma amizade e passam a trocar conhecimentos. Tainá ajuda Joninho a segurar uma cobra (pinó), e Joninho conta para a menina sobre as delícias da cidade e sobre como é bom comer fritas.

SCHEFER, Maria Cristina; FERREIRA, Tássia Monni. Três vezes Tainá, possíveis contribuições de películas indigenistas para os anos iniciais do ensino fundamental. Revista da FUNDARTE. Montenegro, p.01-25, ano 20, no 41, Abril/Junho de 2019.

Disponível em: http://.seer.fundarte.rs.gov.br/index.php/RevistadaFundarte/index> 30 de junho de 2020. 


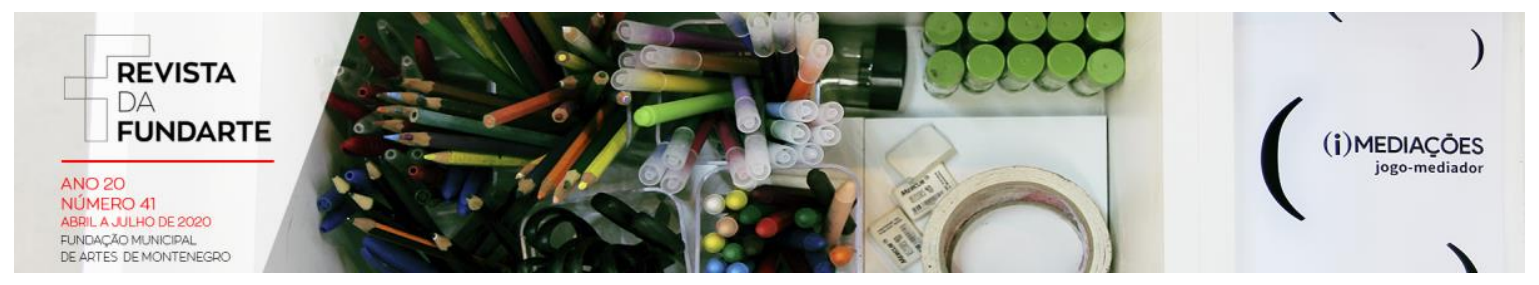

Tainá continua fazendo contato com seu avô, algo comum na cultura indígena, segundo a qual há um plano onde vivem os antepassados, podendo esses se conectar mediante rituais ou sonhos. Em um desses sonhos, Tainá recebe de Tigê um amuleto, o muiraquitã, que, segundo o ancestral, tinha o poder de proteger a menina de qualquer mal, dando-lhe coragem e força.

Tainá e Joninho seguem juntos para a mata, com a intenção de salvar animais silvestres, missão que é cumprida com a ajuda de Tikiri (filha de um dos contrabandistas).

No final do filme, Tainá salva o macaquinho Catu e retorna para a sua aldeia na floresta. Como guardiã, ela entende que não pode viver entre os homens comuns e, em meio a efeitos especiais, ela simplesmente some no ar como se fosse um espírito da natureza. Os contrabandistas são presos.

Em Tainá, a aventura continua (2004), a indígena é adolescente e continua protegendo a floresta onde vive e os animais. Outra criança indígena a acompanha nessas lutas, Catiti. Nesse filme, Tainá tem a missão de expulsar da floresta os invasores que são traficantes de espécimes raros; ela e Catiti inutilizam as armadilhas dos vilões.

Em uma dessas batalhas na floresta, as indígenas encontram Carlito, garoto da cidade que está à procura do seu cachorrinho Bóris, que havia se perdido e que estava sob os cuidados de Catiti.

No primeiro momento, Catiti, Tainá e Carlito não se deram bem, devido ao fato de Carlito querer levar o cãozinho de volta para casa e de Catiti entender que este lhe pertencia, que era o seu xerimbabo (animal de estimação). Porém, desfeito o mal-entendido inicial, apesar das diferenças culturais, o menino acaba se solidarizando com a tristeza da criança indígena e permite que ela se mantenha próxima de Bóris.

Na sequência, Carlito une-se a Tainá e a Catiti na luta contra os bandidos, em defesa da natureza. Juntas, as crianças, portando um chocalho mágico, vencem a batalha final na trama contra os contrabandistas e libertam todos os filhotes, que voltam para a mata.

SCHEFER, Maria Cristina; FERREIRA, Tássia Monni. Três vezes Tainá, possíveis contribuições de películas indigenistas para os anos iniciais do ensino fundamental. Revista da FUNDARTE. Montenegro, p.01-25, ano 20, no 41, Abril/Junho de 2019.

Disponível em: http://.seer.fundarte.rs.gov.br/index.php/RevistadaFundarte/index> 30 de junho de 2020. 


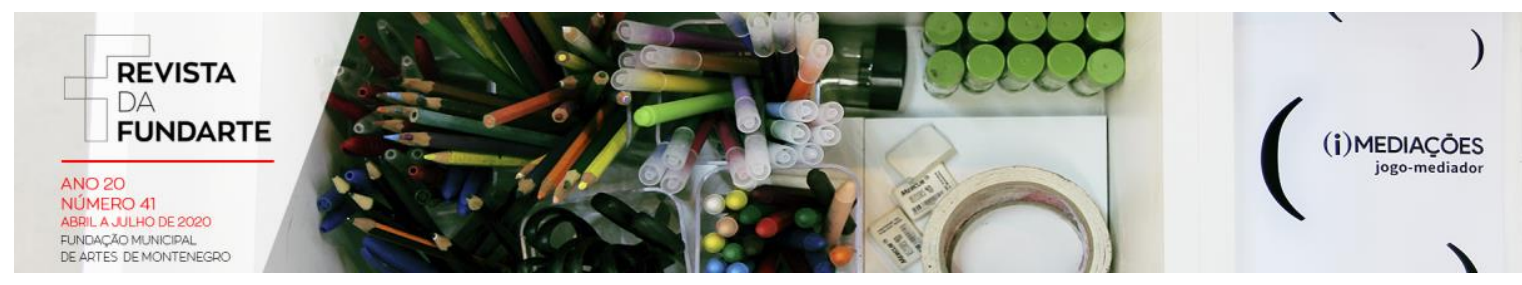

Nas cenas finais do filme, Catiti, muito tristonha, despede-se de Bóris, que parte com Carlito. Ao retornar para a floresta, ela encontra um cesto contendo um gatinho do mato (jaguatirica). Tainá comemora com a criança o fato de que agora ela tem o seu xerimbabo.

Já em Tainá, a origem (2013), a floresta é invadida por piratas da biodiversidade, que roubam o mapa da árvore da vida. Nessa narrativa, é revelado que Maya (mãe falecida de Tainá) tinha sido vítima do mesmo grupo no passado, deixando Tainá ainda bebê. Tainá, que cresceu com o avô, precisou enfrentar o preconceito de alguns meninos das aldeias vizinhas, já que gostava de arco e flecha e se definia como corajosa.

Entretanto, como é revelado na trama, a ancestral Maya havia sido uma guerreira, logo, caberia aos indígenas aceitarem que Tainá herdou o dom da mãe. Essa condição foi anunciada pelos espíritos da floresta, quando permitiram que a menina, e não os demais meninos indígenas, em uma disputa acirrada, recuperasse a flecha azul.

Entre os meninos indígenas, um se destacou na narrativa: Gobi. Ele era alfabetizado e passava os dias teclando em um laptop. Junto com Tainá, Gobi conhece Laurinha, menina branca que se perdeu na floresta e que passa a ajudá-los na luta para a proteção da floresta.

No final da trama, Tainá é encorajada pela mãe a utilizar a flecha azul, objeto mágico que se transforma em pinó-pinó-pinó (cobra muito venenosa) e permite que ela vença o espírito mal, encarnado em Vitor, vilão da história.

\section{DO MATERIAL, DOS ACHADOS E A ANÁLISE}

Enquanto pesquisadoras telespectadoras, acabamos percebendo semelhanças na estrutura dos filmes. Nas três narrativas, há um problema inicial, relacionado à exploração ilegal de recursos naturais da Amazônia, no território do Pará. A protagonista Tainá é ajudada por crianças brancas/indígenas, parentes destas e ancestrais (mãe e avô); os antagonistas, ou anti-heróis, são adultos com

SCHEFER, Maria Cristina; FERREIRA, Tássia Monni. Três vezes Tainá, possíveis contribuições de películas indigenistas para os anos iniciais do ensino fundamental. Revista da FUNDARTE. Montenegro, p.01-25, ano 20, no 41, Abril/Junho de 2019.

Disponível em: http://.seer.fundarte.rs.gov.br/index.php/RevistadaFundarte/index> 30 de junho de 2020. 


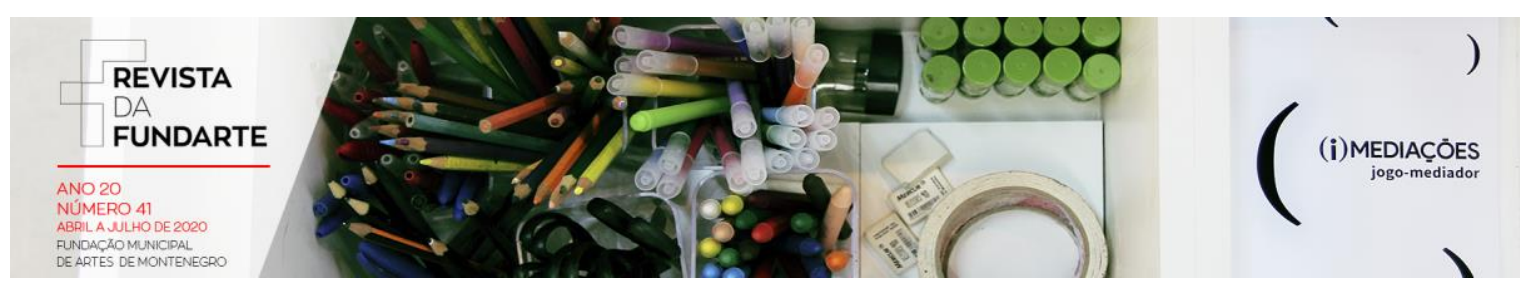

interesses financeiros na fauna e na flora. Ao final das narrativas, os vilões são castigados, e a floresta e seus seres são salvos.

Diante dessas características comuns nos três episódios, é possível dizer que as narrativas se aproximam de contos populares, gênero textual de origem oral. Segundo Schefer (2008, p. 16), "trata-se de narrativa curta, de uma situação específica que requer um desfecho final. Tem um pequeno número de personagens que desempenham funções de fácil identificação (heróis, antagonistas, ajudantes de herói)". Além disso, em contos populares, é comum a inclusão de um auxiliar ou objeto mágico. No quadro que segue, essa estrutura, mesmo não sendo rígida, pode ser visualizada.

Quadro 2 - Evidências de que as narrativas se assemelham a contos populares

\begin{tabular}{|c|c|c|c|c|c|}
\hline $\begin{array}{l}\text { Problema } \\
\text { desencadeador }\end{array}$ & Herói & $\begin{array}{l}\text { Ajudante de } \\
\text { herói }\end{array}$ & Anti-herói & $\begin{array}{l}\text { Elemento } \\
\text { mágico }\end{array}$ & $\begin{array}{l}\text { Desfecho } \\
\text { final }\end{array}$ \\
\hline $\begin{array}{lr}\text { 2000: Catu, } & \\
\text { macaquinho } & \text { em } \\
\text { extinção, é } \\
\text { capturado por } \\
\text { contrabandistas }\end{array}$ & Tainá & $\begin{array}{l}\text { Joninho } \\
\text { Isabel } \\
\text { Rudi }\end{array}$ & $\begin{array}{l}\text { Boca } \\
\text { Biriba } \\
\text { Miss Meg } \\
\text { Mister } \\
\text { Smith } \\
\end{array}$ & $\begin{array}{l}\text { Amuleto } \\
\text { dado pelo } \\
\text { avô, Tigê }\end{array}$ & $\begin{array}{l}\text { Tainá salva } \\
\text { Catu, e os } \\
\text { vilões são } \\
\text { castigados. }\end{array}$ \\
\hline $\begin{array}{lr}2004: & \text { Traficantes } \\
\text { de espécimes raros } \\
\text { capturam } & \text { os } \\
\text { xerimbabos } & \\
\text { (animais } & \text { de } \\
\text { estimação } & \text { dos } \\
\text { indígenas) } & \end{array}$ & Tainá & $\begin{array}{l}\text { Catiti } \\
\text { Carlito } \\
\text { Gaspar }\end{array}$ & $\begin{array}{l}\text { D. Zuzu } \\
\text { Carcará } \\
\text { Lacraia } \\
\text { Zé Grilo }\end{array}$ & $\begin{array}{l}\text { Chocalho } \\
\text { do Pajé } \\
\text { Tatu Pituna }\end{array}$ & $\begin{array}{l}\text { Tainá salva } \\
\text { os } \\
\text { xerimbabos, } \\
\text { e os vilões } \\
\text { são } \\
\text { castigados. }\end{array}$ \\
\hline $\begin{array}{l}\text { 2013: Piratas da } \\
\text { biodiversidade } \\
\text { roubam o mapa } \\
\text { que mostra a } \\
\text { localização da } \\
\text { árvore sagrada } \\
\text { (sapopema). }\end{array}$ & Tainá & $\begin{array}{l}\text { Laurinha } \\
\text { Gobi } \\
\text { Teodoro } \\
\text { (Ancestrais: } \\
\text { Maya-Tigê) }\end{array}$ & $\begin{array}{l}\text { Vitor } \\
\text { Luna } \\
\text { Bu }\end{array}$ & $\begin{array}{l}\text { Flecha } \\
\text { azul }\end{array}$ & $\begin{array}{l}\text { Tainá salva a } \\
\text { árvore } \\
\text { sagrada, e o } \\
\text { vilão é morto. }\end{array}$ \\
\hline
\end{tabular}

(Fonte: autoras, 2019)

Com o objetivo de verificarmos os conhecimentos sobre a cultura indígena, bem como as potencialidades das narrativas para a Educação Ambiental, organizamos outro quadro, para o qual selecionamos trechos de diálogos entre

SCHEFER, Maria Cristina; FERREIRA, Tássia Monni. Três vezes Tainá, possíveis contribuições de películas indigenistas para os anos iniciais do ensino fundamental. Revista da FUNDARTE. Montenegro, p.01-25, ano 20, no 41, Abril/Junho de 2019.

Disponível em: http://.seer.fundarte.rs.gov.br/index.php/RevistadaFundarte/index> 30 de junho de 2020. 


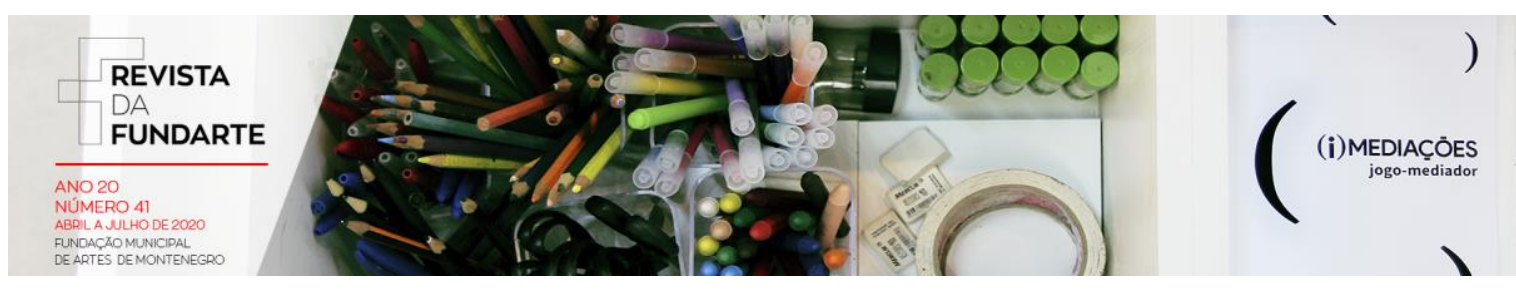

Tainá e seus ajudantes (crianças/adultos) ou com seus ancestrais. Os diálogos demonstram o quanto a cosmologia desse povo tradicional está presente, tendo sido objeto de estudo dos produtores dos três filmes.

Quadro 3- Educação Ambiental e Cultura Indígena

\begin{tabular}{|c|c|}
\hline Título/ Tema & Falas indígenas: \\
\hline $\begin{array}{l}\text { Tainá, uma aventura na } \\
\text { Amazônia (2000) } \\
\text { (Contrabandistas queriam } \\
\text { um macaco em extinção) }\end{array}$ & $\begin{array}{l}\text { a) "Tem que lutar contra a maldade dos homens, } \\
\text { senão, a floresta e os bichos morrem e do mundo só } \\
\text { restará um nada". (Indígena falando com Tainá) } \\
\text { b) "Índio não morre, vira pássaro, vira bicho, vira } \\
\text { floresta". (Indígena falando com Tainá) }\end{array}$ \\
\hline $\begin{array}{l}\text { Tainá, a aventura continua } \\
\text { (2004) }\end{array}$ & $\begin{array}{l}\text { a) "Aquele que faz mal à floresta, faz mal a si } \\
\text { mesmo". (Indígena falando com Tainá) }\end{array}$ \\
\hline $\begin{array}{l}\text { (Contrabandistas queriam } \\
\text { espécies raras de animais) }\end{array}$ & $\begin{array}{l}\text { b) "Os filhotes são da floresta Catiti, têm mãe para } \\
\text { cuidar deles. A gente só pode pegar um filhote } \\
\text { quando ele não tem ninguém". (Tainá ensinando } \\
\text { outra criança indígena) }\end{array}$ \\
\hline $\begin{array}{l}\text { (Piratas da biodiversidade } \\
\text { queriam localizar a árvore } \\
\text { sagrada) }\end{array}$ & $\begin{array}{l}\text { a) "Menina não pode brincar com arco e flecha". } \\
\text { (Menino indígena falando com Tainá). } \\
\text { b) "Sem a floresta, só vai restar um nada". (Indígena } \\
\text { falando com Tainá) }\end{array}$ \\
\hline
\end{tabular}

(Fonte: as autoras, 2019)

Como demonstramos, nas três narrativas, há ensinamentos sobre o respeito que os indígenas têm pela natureza. A pertença à mata como parte de ciclos de vida (pessoa vira bicho, bicho vira pessoa) foi ressaltada em vários momentos nas tramas. Segundo Cavallo (2018, p. 375),

quando falamos de conhecimento indígena tradicional, não só nos referimos aos distintos saberes e sabedorias acumuladas através dos séculos de existência e civilização, como também às formas distintas de ver o mundo, isto é, a visão holística pela qual a existência humana é descoberta pelas comunidades indígenas.

SCHEFER, Maria Cristina; FERREIRA, Tássia Monni. Três vezes Tainá, possíveis contribuições de películas indigenistas para os anos iniciais do ensino fundamental. Revista da FUNDARTE. Montenegro, p.01-25, ano 20, no 41, Abril/Junho de 2019.

Disponível em: http://.seer.fundarte.rs.gov.br/index.php/RevistadaFundarte/index> 30 de junho de 2020. 


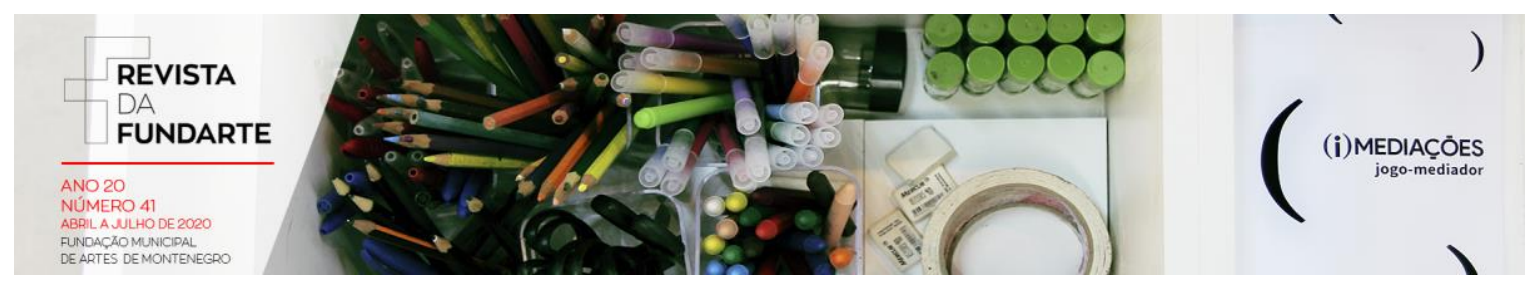

$\mathrm{Na}$ contramão dessa compreensão de pertença à natureza e de um compromisso místico/real com a fauna e a flora, não indígenas assumem posturas de vilões, de exploradores e espoliadores, nas narrativas. Salientamos, nesse sentido, a fala predatória de um dos contrabandistas de animais silvestres em Tainá, uma aventura na floresta (2000): "Eu ponho o bicho vivo dentro do avião. Se ele chega morto, fazer o quê? Não fui eu quem fabricou, foi a natureza, reclamem com ela" (fala do personagem Boca).

A questão da diferença de gênero, do que (não) cabe à menina indígena, é tratada na última narrativa produzida, Tainá, a origem (2013). Inicialmente, foi enfatizado que caberia apenas aos meninos o uso do arco e da flecha; na sequência, isso é revisto, a partir da ideia de que há exceções definidas pelo "espírito da floresta", e é ele quem pode dar a uma menina o poder de guerreira.

Nesse episódio, uma das questões interessantes é que Tainá deixa claro que ser corajosa não é não ter medo, mas saber lidar com ele. Ela ensina à criança branca que basta cantar algo assim: "Toque patoque; Patoque toque; Tiquetê, tiquetê; Tumba, tumba; Tumba, tumba" (canto de Tainá).

Vale dizer que, nas três narrativas, crianças e adolescentes se unem para preservar a natureza, inclusive, no filme Tainá, uma aventura na floresta (2000), a filha de um dos contrabandistas questiona a atitude do pai (que envia animais em extinção para o exterior). Este, com descaso, responde: "E daí? Os dinossauros também não acabaram, e alguém sentiu falta dos bichinhos?" (fala do personagem Boca).

Chama atenção, na narrativa Tainá, a aventura continua (2004), o fato de um menino indígena ser nerd, alfabetizado, e utilizar um laptop; talvez, por conta disso, não pareceu muito interessado nas brincadeiras das demais crianças da aldeia, já que ele não quis participar da corrida pela flecha azul, atividade que determinaria um novo guerreiro. Esse indígena, de nome Gobi, fez amizade com a menina branca Laurinha, que se perdeu na floresta; ela carregava uma boneca falante e registrava seu dia a dia em um diário.

SCHEFER, Maria Cristina; FERREIRA, Tássia Monni. Três vezes Tainá, possíveis contribuições de películas indigenistas para os anos iniciais do ensino fundamental. Revista da FUNDARTE. Montenegro, p.01-25, ano 20, no 41, Abril/Junho de 2019.

Disponível em: http://.seer.fundarte.rs.gov.br/index.php/RevistadaFundarte/index> 30 de junho de 2020. 


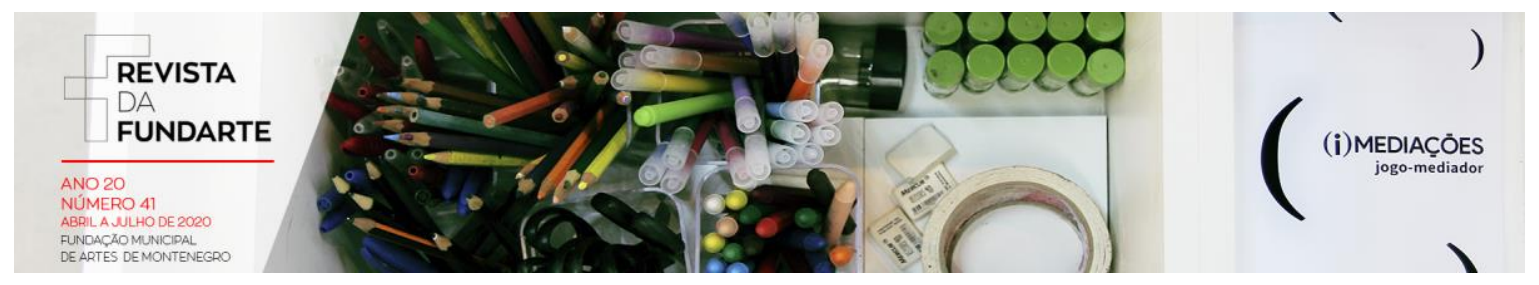

A sensibilidade infantil e a capacidade que as crianças têm de fazerem amizades sinceras, independentemente de questões étnico-raciais, foram evidenciadas nas três narrativas, junto ao desejo de se fazerem heróis pela natureza. Enfim, recomendamos Tainá em suas três produções!

\section{CONSIDERAÇÕES FINAIS}

Este estudo buscou analisar as potencialidades dos três episódios de Tainá, produzidos entre 2000 e 2013, para uso didático-pedagógico na escola. O resultado da investigação revelou que as narrativas podem atender aos objetivos da legislação educacional quanto ao ensino da cultura afro-indígena, à Educação Ambiental, à obrigatoriedade da exibição por duas horas semanais de filmes nacionais e à Base Nacional Curricular Comum (BNCC), no que diz respeito a oferecer aos alunos dos anos iniciais do Ensino Fundamental outros suportes textuais, como os filmes, entendidos como linguagens contemporâneas.

As três narrativas, que se assemelham a contos populares, pela estrutura simples, permitem, em um exercício fantasioso, a tomada de consciência sobre a questão ambiental, sobre a exploração inconsequente dos recursos naturais da Amazônia e o exemplo indígena de uso respeitoso desses recursos. Pensando na idade entre os seis e onze anos, em que as crianças frequentam os anos iniciais do Ensino Fundamental no Brasil, o contato com a luta de Tainá para proteger a natureza pode permitir empatia (dos telespectadores) com a luta indígena no Brasil, no estado e na região do Litoral Norte (RS). Diante disso, cabe-nos recomendar Tainá em suas três produções.

\section{Referências:}

BAUMAN, Zygmunt. Vida para o consumo: a transformação das pessoas em mercadoria. Rio de Janeiro: Zahar, 2008.

BEHREND, Danielle Monteiro; COUSIN, Cláudia da Silva; GALIAZZI, Maria do Carmo. Base Nacional Comum Curricular: o que se mostra de referência à Educação

SCHEFER, Maria Cristina; FERREIRA, Tássia Monni. Três vezes Tainá, possíveis contribuições de películas indigenistas para os anos iniciais do ensino fundamental. Revista da FUNDARTE. Montenegro, p.01-25, ano 20, no 41, Abril/Junho de 2019.

Disponível em: http://.seer.fundarte.rs.gov.br/index.php/RevistadaFundarte/index> 30 de junho de 2020. 


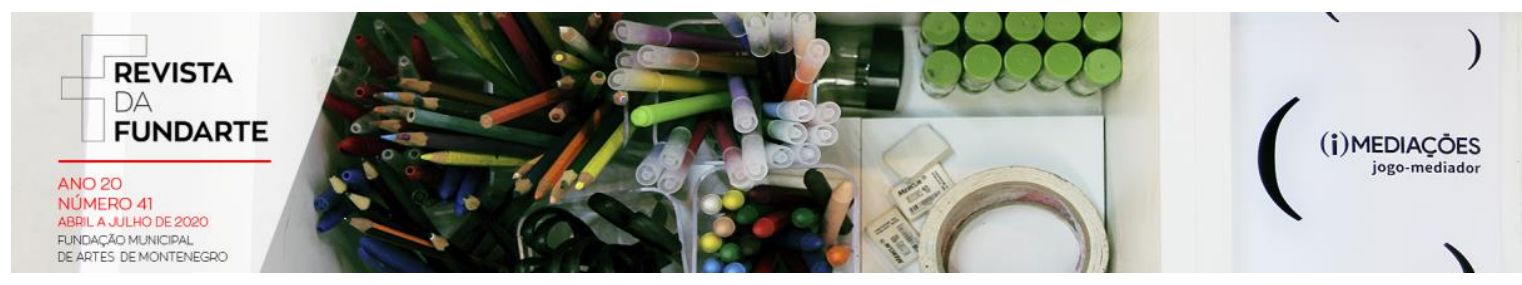

Ambiental? In: Ambiente \& Educação -Revista de Educação Ambiental Programa de Pós-Graduação em Educação Ambiental Universidade Federal do Rio Grande do Sul- FURG. ISSN 1413-8638 E-ISSN- 2238-5533 Edição Especial para o X Encontro e Diálogos com a Educação Ambiental- EDEA Vol. 23, n. 2, 2008.

BRASIL. Constituição

Federal.

Disponível em: http://www.planalto.gov.br/ccivil_03/Constituicao/Constituicao.htm. Acesso em: 09 de nov. 2019.

Educação Ambiental. Disponível em: http://www.planalto.gov.br/ccivil_03/leis/19795.htm. Acesso em: 10 de nov. 2019.

. Lei ํo 11.645 de 10 de março de 2008. Altera a Lei o 9.394, de 20 de dezembro de 1996, modificada pela Lei ㄲo 10.639, de 9 de janeiro de 2003, que estabelece as diretrizes e bases da educação nacional, para incluir no currículo oficial da rede de ensino a obrigatoriedade da temática "História e Cultura AfroBrasileira e Indígena". Disponível: http://legis.senado.leg.br/norma/569484. Acesso em: 11 de nov. 2019.

Resolução ํo 2, de 15 de junho de 2012. Estabelece as Diretrizes Curriculares Nacionais para a Educação Ambiental. Diário Oficial da União. Brasília: DOU, 2012. Disponível em: http://portal.mec.gov.br/dmdocuments/rcp002_12.pdf. Acesso em: 10 de nov. 2019.

Lei o 13.006, de 26 de junho de 2014. Acrescenta $\S 8^{\circ}$ ao art. 26 da Lei no 9.394, de 20 de dezembro de 1996, que estabelece as diretrizes e bases da educação nacional, para obrigar a exibição de filmes de produção nacional nas escolas de educação básica. Disponível em: http://www.planalto.gov.br/ccivil_03/_Ato2011-2014/2014/Lei/L13006.htm. Acesso em: 11 de nov. 2019.

. Ministério da Educação. Secretaria da Educação Básica. Base nacional comum curricular. Brasília, DF, 2016. Disponível em: http://basenacionalcomum.mec.gov.br/\#/site/inicio. Acesso em: 12 de nov. 2019.

CAVALLO, Gonzalo Aguilar. Conhecimentos ecológicos indígenas e recursos naturais: a descolonização inacabada. In: Estudos Avanços, São Paulo, v. 32, n. 94, p. 373-390, set.- dez. 2018.

DUARTE, Rosália. Cinema \& educação. BH: Autêntica, 2002.

FABRIS, Eli. Em Cartaz - O cinema brasileiro produzindo sentidos sobre escola e trabalho docente. Porto Alegre, UFRGS, 2005, 250 p., Tese (Doutorado) - Programa

SCHEFER, Maria Cristina; FERREIRA, Tássia Monni. Três vezes Tainá, possíveis contribuições de películas indigenistas para os anos iniciais do ensino fundamental. Revista da FUNDARTE. Montenegro, p.01-25, ano 20, no 41, Abril/Junho de 2019.

Disponível em: http://.seer.fundarte.rs.gov.br/index.php/RevistadaFundarte/index> 30 de junho de 2020. 


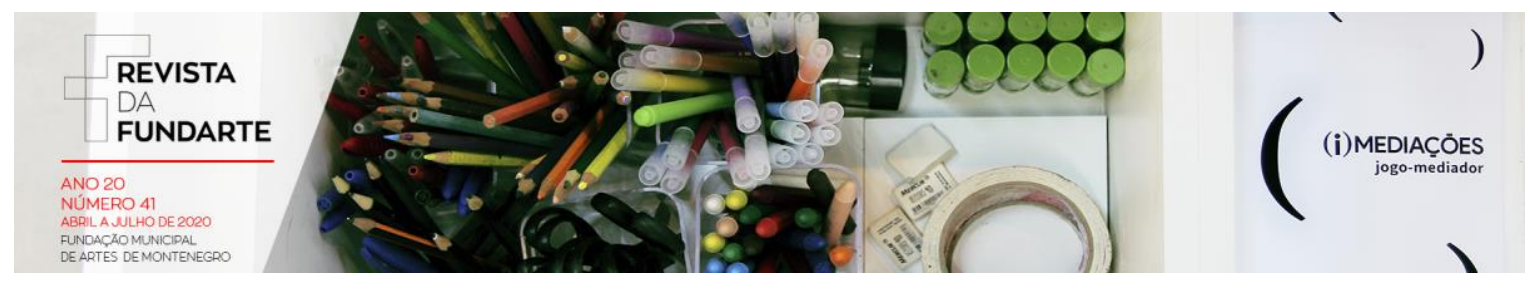

de Pós-Graduação em Educação, Faculdade de Educação, Universidade Federal do Rio Grande do Sul, Porto Alegre, 2005.

GOBBI, Flávio Schardong; Baptista, Marcela Meneghetti; PRINTES, Rafaela Biehl; COSSIO, Rodrigo Rasia. Breves aspectos socioambientais da territorialidade MbyáGuarani no Rio Grande do Sul. In: Coletivos Guarani no Rio Grande do Sul: territorialidade, interetnicidade, sobreposições e direitos específicos. Assembleia Legislativa do Estado do Rio Grande do Sul / Comissão de Cidadania e Direitos Humanos Porto Alegre: ALRS/CCDH, 2010.

PREZIA, Benedito. História da resistência indígenas: 500 anos de história. São Paulo: Expressão Popular, 2017.

RIO GRANDE DO SUL. Assembleia legislativa. Relatório Azul, garantias e violações dos direitos humanos. Porto Alegre, RS: Comissão de cidadania e direitos humanos, 2017.

SAUTCHUK, Jaime. Cacique Raoni, defensor da Amazônia e dos povos da floresta. In: Xapuri Socioambiental. Acre: Comunicação e Projetos Ltda, n. 60, p. 09-14. out. 2019.

SCHEFER, Maria Cristina. Dos Grimm a Câmara Cascudo: um caso de tradução cultural. 2008 (103 f.) Dissertação (Mestrado em Letras e Cultura Regional). Caxias do Sul: Universidade de Caxias do Sul, RS, 2008.

Teko Jeapo, a escola indígena autônoma Sul do Brasil: Inovação Etnoinstitucional, Já! Revista Euroamericana de Antropologia, n. 8, p. 105-116, ago./dez. 2019.

SOUZA, José Otávio Catafesto de. Indígenas no Rio Grande do Sul: breve relato sobre grupos humanos autóctones no sul do Brasil. In: Da África aos indígenas do Brasil: caminhos para o estudo de História e Cultura Afro-Brasileira e Indígena. Porto Alegre: UFRGS, 2016.

TAINÁ uma aventura na Amazônia. Direção: Tânia Lamarca; Sérgio Bloch/M.A Marcondes Pedro Rovai. Rio de Janeiro: Tietê produções cinematográficas, M.A. Marcondes Art films: 2001. 1 DVD.

TAINÁ a aventura continua 2. Direção : Mauro Lima/ Produção Pedro Carlos Rovai, Virginia Limberger e Erica lootty. Rio de Janeiro: Tietê produções cinematográficas, globo filmes, Columbia Tristar filmes, 2004. 1 DVD.

TAINÁ 3 a origem. Direção: Rosane Svartman/ Produção Pedro Rovai. Rio de Janeiro: Globo Filmes, 2013.

SCHEFER, Maria Cristina; FERREIRA, Tássia Monni. Três vezes Tainá, possíveis contribuições de películas indigenistas para os anos iniciais do ensino fundamental. Revista da FUNDARTE. Montenegro, p.01-25, ano 20, no 41, Abril/Junho de 2019.

Disponível em: http://.seer.fundarte.rs.gov.br/index.php/RevistadaFundarte/index> 30 de junho de 2020. 